\title{
POSSIBILITIES FOR PRE-SCHOOL EDUCATION STUDENTS TO COMBINE STUDIES AND WORK: EMPLOYERS' POSITION
}

\author{
Algimantas Bagdonas, Asta Jakimavičienè, \\ Raimonda Sadauskienè, Sigita Saulènienè \\ Kauno kolegija / University of Applied Sciences, Lithuania
}

\begin{abstract}
Practice of higher education institutions reveals that many students start working during their studies and some of them enter higher education institutions already being employed. The vast majority of pre-school education students who study in part-time studies have been already working since the first year of their studies or are already in practice. In the process of combining studies with the work there is a need to find out the problems that students face while entering the world of work trying to combine studies and work, and to determine the employers' attitude towards the studying employees revealing the essential characteristics of working students. The research was carried out in two stages. In the first stage of the research the studying conditions in higher education system of Lithuania, the experience of students in the labor market and good practices of applying student-friendly measures in combining studies and work in the European Union were discussed. The second part of the work presents the data and the results. The study revealed that half of the students who participated in the study were employed and that most of the students start working in the first year of their studies. Research problem - what is employers' attitude towards the pre-school education students' ability to combine studies and work? Research aim - to reveal employers' attitude towards students' possibilities to combine studies and work. Research objectives: to determine employers' attitude towards studying employees. To substantiate possibilities of combining studies and work. To reveal the essential employees' characteristics required for a working student. Research methods: document analysis and a questionnaire/ survey. The results of the research revealed that the employers' attitude towards studying employees is favorable.
\end{abstract}

Keywords: combining work and studies, employment, part-time studies, pre-school education, professional competencies.

\section{Introduction}

According to the data of 2020 in Lithuania the share of the first and the second cycle working students who work during the whole academic year 
makes up more than a third of all studying students. On average more than 30 hours per week are spent for work. The number of working students is increasing every year. In Lithuania most often are employed students who are over 30 years of age, studying in master's degree programs, students entering universities or colleges after a break after high school graduation, studying social sciences and humanities or studying in part-time studies. In Lithuania first-year students choose jobs that are easy to combine with their studies: they work in the evenings, on a rolling schedule, at weekends, usually in the service or trade sector (State of Lithuanian Studies, 2020). However, senior students are already starting to look for jobs that are relevant to their studies. Students start working earlier and more often for several reasons: to have financial freedom and because they are no longer dependent on their parents. Employment helps young people to develop the qualities they would need in their future life, to develop time planning skills, as everyone tries to keep up not only with the work but also with learning and to find time for the hobbies, too (Beerkens, Mägi, \& Lill, 2011). There are certain exceptions for a working student in Lithuania: it is possible to work part-time: to work less than 8 hours per day and 40 hours during the week. Part-time work during a working day or a working week is determined by the agreement between the learner and the employer (agreement of both parts is required). Study leave is granted: upon submission of a certificate regarding the examinations, passing of credits and the dates of their holding, the studying employee is entitled to get the study leave of the planned duration. The employer having assessed the purpose of such leave must provide it. Annual leave can be combined with the learning needs of a working student: the employer must satisfy the request for an annual leave if the employee is studying without interrupting work, combining annual leave with examinations, credit tests, preparation of diploma theses, laboratory work and consultation time (State of Lithuanian Studies, 2020). Work experience (especially relevant to the field of study) can increase students' competitiveness and facilitate the transition to the labor market. Due to the high workload the time spent on studies and integration into the social and academic community of the higher institution (university/college) may decrease. This may contribute to the deterioration of academic achievements, increase the probability of non-completion of studies (Lukšas, 2019; Šerènaitè, 2020; Urbonaitè - Vainienè, Brunalas, 2018).

Research problem - what is employers' attitude towards the pre-school education students' ability to combine studies and work?

Research aim - to reveal employers' attitude towards the students' possibilities to combine studies and work.

\section{Research objectives:}

1. To determine employers' attitude towards the studying employees. 
2. To substantiate possibilities of combining studies and work.

3. To reveal the essential employees' characteristics required for a working student.

Research methods: document analysis and a questionnaire/survey.

\section{Possibilities to combine studies and work}

In 2019 the share of working first cycle students among university and college students respectively was 32 and 50 percent. According to the results of an international survey in Lithuania the share of the first- and the second-cycle working students who work during the whole academic year makes up more than a third of all studying students. On average, they spend more than 30 hours per week on work. According to these indicators, Lithuania is in a higher than average position among other EU countries. In the EU, an average of $35 \%$ of students work throughout their studies. Work experience (especially relevant to the field of study) can increase students' competitiveness and facilitate the transition to the labor market. It is noticeable that due to the high workload, the time spent on studies and integration into the social and academic community of the higher institution may decrease. This may contribute to the deterioration of academic achievements and increase the probability of non-completion of studies (State of Lithuanian Studies, 2020).

According to the carried-out researches and the data of the center for monitoring and analysis in science and studies the number of working students is growing across Europe. A study done by Eurostudent in 28 European countries shows that, on average, more than half of all students in European higher education institutions combine their studies and work. The number of working students ranges from 15 percent in Italy, Albania, Serbia to more than 50 percent in Germany, Romania, Estonia, Lithuania. About 85 percent of students work in Ireland. In all European countries students who work during their studies on regular basis or part -time jobs, mostly are employed for financial reasons. These reasons are particularly common among older students, students without higher education and students living apart from their parents. On average, 69 percent of these students work to cover their living expenses. On average, one out of five working students financially supports other family members - a partner, children or parents. Besides financial reasons almost 60 percent of working students note that they choose a job in order to gain experience in the labor market and to improve employability skills (State of Lithuanian Studies, 2020).

Work during the studies not only provides financial stability, but also allows students to gain valuable experience, enter the labor market and sometimes discover their career path. However, combining study and work 
can be a difficult task. So how to keep balance and keep things on time without compromising neither studies nor the start of career? Nowadays we have enough students who are keen to combine studies and work. However, young people are often discouraged from starting to work by a simple fear that they will not be able to succeed in studies and achieve good results at work at the same time. Often young people simply do not dare to try or to find a suitable work format for them. Still, real experience shows that a successful combination of work and study is certainly possible. The company seeks to create conditions that would allow a studying employer not to push his/her studies aside (Combining studies and science, 2020, p. 13).

Half of the students who raise children also indicated that they had to look for additional work to improve financial situation of their families. This and the above-mentioned consequences are significantly related as the work, study and family harmonization tensions affect the physical and psychological well-being of students. The most attractive measures for combining students' studies and work are based on teachers' positive attitude towards working students, possibility to be provided with free attendance and individual study schedule.

The combination of study and work is more relevant for master's and part-time students. One of the most important things to successfully combine study and work is good time planning and efficient agenda allocation. Work in shifts with a flexible schedule is the most suitable for this. Flexibility in the work schedule is a key to the balance between study and work. Being able to express student's preferences for working hours makes it easier for a person to plan days and weeks in a way to pay enough attention to both study and work. For example, a number of studying colleagues choose the opportunity to work in the evenings or work when they are not busy at studies. Employer's involvement is also important. Even if a job has flexible work schedule situations occur for a studying staff when their important reports or lectures at the university coincide with the intensive periods at work. These are moments when many working students face the greatest challenges. It happens often when not only a very intensive period at work and at the university coincides but when personal matters also put pressure. In such cases it is really easy to "burn out". However, even these situations can be managed with the involvement of the employer. The situation is stabilized by only a few extra days for so-called academic holiday (Sanchez-Gelabert, Figueroa, \& Elias, 2017).

Stress management sessions also work as an appropriate prevention during which psychologists help to solve various challenges that arise during work, including time planning, study and work coordination. "One of the most important aspects to avoid stressful situations is to communicate with the employer about the situation. There is a need for mutual 
understanding - both the employer should be more flexible about the needs of students and colleagues should announce the need for study days as early as possible (Šerènaitè, 2020, p. 8). One of the most common mistakes students make when they want to work is the desire to cover too much material. Often people who combine studies and work slightly overestimate their strengths. They want to work full-time and study, attend additional subjects and courses at the university, as well as to devote enough time to their interests and hobbies. Some manage to do this but it requires discipline and good time planning skills. As a result, you should realistically assess your options and plan your activities wisely, for example, you may be able to start with a part-time job instead of a full-time job. Then watch how it goes and only then increase the volume of work" (Combining studies and science, 2020, p. 14). Possibilities to combine studies and professional activities need to be seen from both the work and a higher education institution's side. There would be no problems at work if students have to spend more time on studies, lectures and if the university also treat working students with understanding, allows them to adjust the dates and deadlines for assessments or research papers. There is a large number of young people seeking synergy between study and work today, so it is important for employers who compete for professionals to enable them to enter the labor market without leaving studies. Otherwise, companies simply reject a significant proportion of potential employees. "It is important for young people to acquire not only theoretical knowledge but also practical skills in real work, and this path begins with time planning and the first steps of career" (Neyt et al., 2017, p. 5; Sanchez-Gelabert et al., 2017, p. 10).

Employers' surveys are of great importance improving students' possibilities to combine work and studies. Such surveys can identify current or future needs or shortage for skills and knowledge needed to perform job functions, as well as companies' human capital strategies, such as employee training and other aspects. The information gathered and systematized through employers' surveys can contribute not only to the development of labor market or employment measures, but also to continuing education programs, long-term strategies for investing in human capital. The main advantage of such employers' surveys is gaining the direct information from employers themselves about the labor market and the situation in a company (Mane, Corbella, 2017, p. 8).

\section{Methodology}

Research method is a survey which was carried out by using questionnaire. The questionnaire survey was conducted in October - November, 2020. The questionnaire was submitted to 55 employers whose organizations 
employ employees studying pre-school education programme at Kauno kolegija/University of Applied Sciences. The questionnaire was prepared on the basis of the theoretical provisions highlighted in the theoretical part of the study. The questionnaire consists of 29 closed-ended questions, one open-ended question which asks for recommendations about the possibilities to combine work and study. When compiling the questionnaire the research questions were divided into the following semantic blocks: questions that delve into the learner's position in a specific organization; issues that go deeper into creating the conditions for the studying employees; issues that delve into the links between the workplace and the educational institution; issues that deepen the employer's attitude towards the studying employees; questions that delve into the individual characteristics of the learner. During the research the volunteerism of the research participants and the anonymity of the research data were ensured. The research data were used in general and for research purposes only.

\section{Analysis and discussion of research data}

Respondents' answers to the question "Indicate the percentage of studying employees in your institution" (Fig. 1), were distributed as follows: working at 0,25 part-time makes up 15 percent, working at 0,5 part-time makes up 36 percent, working at 0,75 part-time makes up 9 percent, working full-time makes up 20 percent. The "other" option was indicated by 20 percent of respondents.

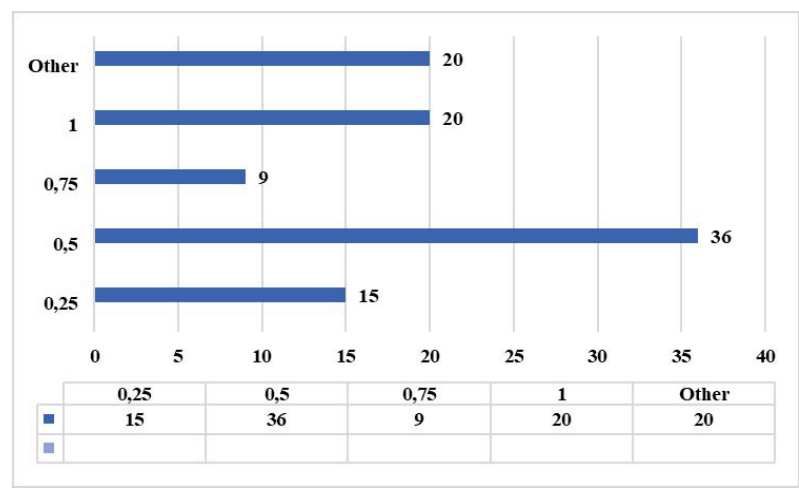

Figure 1. Employment of studying staff in the organization

Summarizing the respondents' answers it can be stated that the vast majority of studying staff work part-time, but a large proportion of students work more than half-time or full-time ( $29 \%$ in total). So, the working 
students work long hours, which is quite a big load - studying full-time and working half and more full-time per month.

Respondents' answers to the question "Studies of the studying employees are mostly a) related to the specialty b) not related to the specialty (Fig. 2), were distributed as follows: 94 percent of the respondents indicated that the students who work in their institution work according to the specialty they are studying and only 6 percent of employers indicated that students working in their institution do not work according to the specialty they are studying.

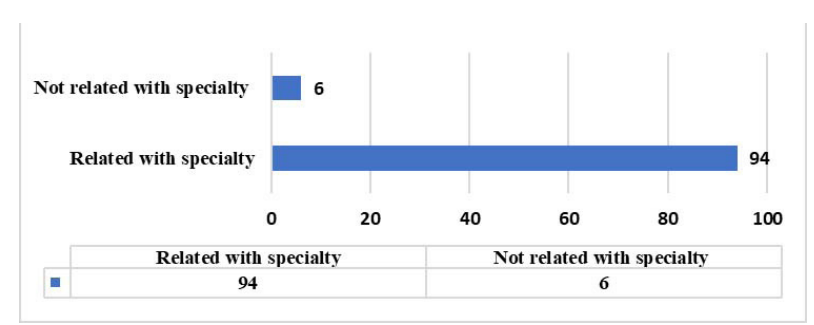

Figure 2. Work and study ratio

Summarizing the answers received by the surveyed employers it can be concluded that the absolute majority of the working students in the surveyed institutions work according to their future specialty. This aspect can be considered as a very positive students' step, a conscious choice to work according to the subject they are studying in order to gain work experience and deepen competencies.

Respondents' answers to the question "As a manager you treat a studying employee: a) with the hope that we will have a highly qualified employee; (b) the same as others; c) I avoid hiring such employees" (Fig. 3), were distributed as follows: 82 percent of employers say that they treat the studying workers with the hope of having a highly qualified employees, 15 percent of respondents say that they treat such employees as everyone else and only 3 percent of employers avoid hiring students for work.

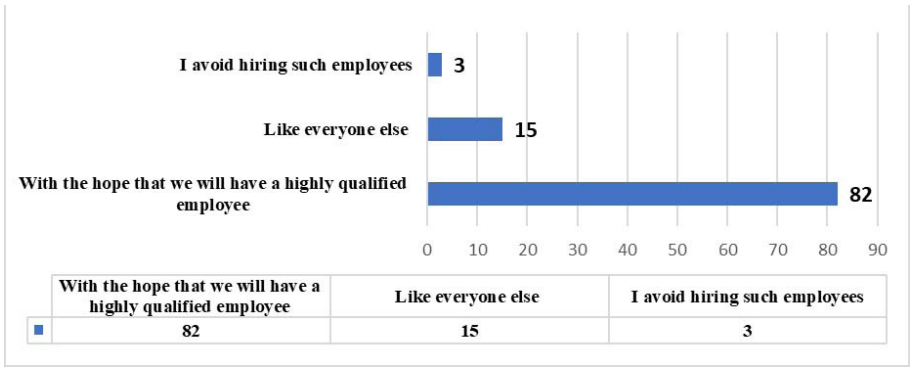

Figure 3. Employers' attitude towards a studying employee 
Summarizing the respondents' answers it can be stated that the absolute majority of surveyed employers have a very positive attitude towards the studying workers, they find it beneficial having students in their organization, understand that after graduation such people will create an added value to the institution.

Respondents' answers to the question "Organization encourages employees to study" (Fig. 4), were distributed as follows: 44 percent of respondents agree or strongly agree with this statement, which indicates that a total number of employers (88\%) assess working students very positively. This shows employers' awareness of the importance of learning, in this way creating a learning organization and creating an added value not only for the individual employee, but also for the organization itself. 6 percent of respondents stated that they disagree with this statement and have no opinion on the matter.

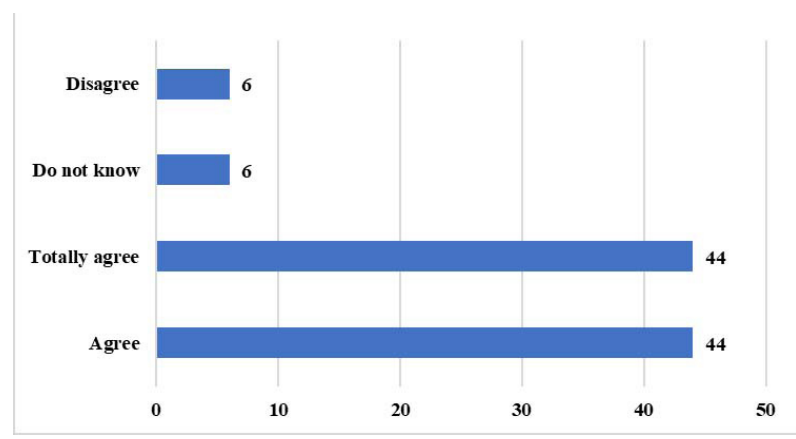

Figure 4. Organization and studies

Summarizing the respondents' answers it can be stated that the interviewed employers consciously encourage employees to study because they see benefits in that for their organization.

Respondents' answers to the question "Studying employees in your institution: a) are able to combine work and studies; (b) are partially able to combine work and study; (c) find it difficult to combine work and study; d) the answer "absolutely unable to combine work with studies" (Fig. 5), were distributed as follows: the vast majority of employers say that more than 70 percent of working students are able to combine work and study and 30 percent point out that working people are partially able to combine work and study. No one indicated that the working students are unable to combine work and study or that it is difficult for the working people to combine work and study.

Summarizing the respondents' answers it can be stated that students manage to fully or partially combine work and studies. Employers do not 
observe fundamental problems in this process. It can be assumed that the work and study process is manageable and there are no major problems.

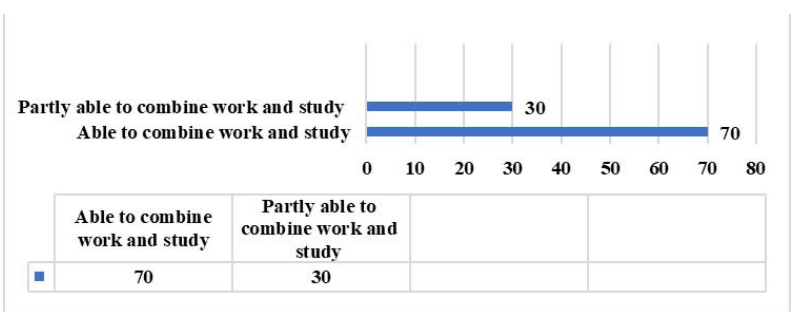

Figure 5. Assessment of the ability to combine work and studies

Respondents' answers to the question "Individual work schedules are created for the studying employees in the organization" (Fig. 6), were distributed as follows: 54 percent of respondents agree with the statement, 33 percent fully agree with the statement, 13 percent disagree with the statement. Summarizing the total data of "agree" and "strongly agree" answers the obtained result (87\%) shows that organizations pay sufficient attention to the individualization of learners' work schedules, that their needs are important to the manager who is interested in employee's studies and learning conditions.

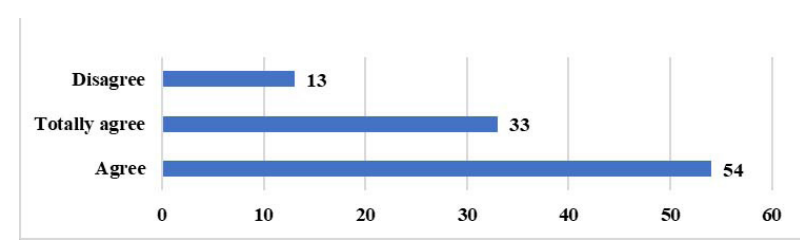

Figure 6. Creating an individual work schedule

Summarizing the respondents' answers it can be stated that employers understand the issues of combining work and studies of the studying worker considering the needs of the employee when creating work schedules.

Respondents' answers to the question "Is it important for the working students that the schedule of studies and examinations would be provided as early as possible" (Fig. 7), were distributed as follows: 38 percent of respondents agree with the statement and 53 percent of them fully agree with the statement. So, the overall percentage of respondents who positively evaluate the pre-submission of the schedule, appropriate information and communication is 91 percent. This shows that cooperation between a higher education institution, a learner and employers is very important in 
this process in order to create favorable conditions for both learning and work performance. 9 percent of respondents indicate that they have no opinion on the matter.

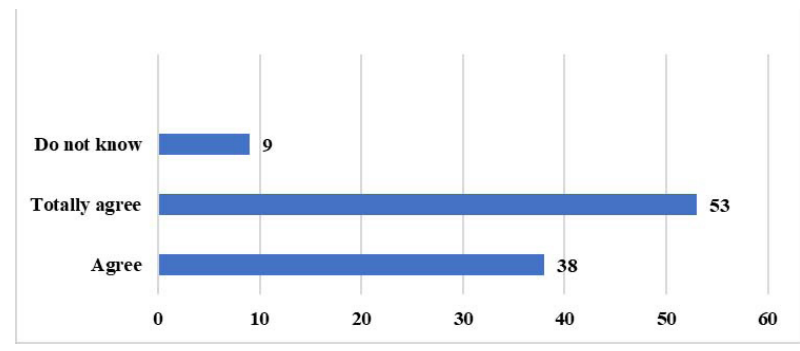

Figure 7. The importance of schedule coordination

Summarizing the respondents' answers it can be stated that employers understand the needs of the studying employees and actually also think about their organization so that work processes do not suffer having studying workers who are assigned to perform the tasks, etc.

Respondents' answers to the question "Relationship with an educational institution is mutually beneficial (e. g. carried out contracted researches, qualification events)" (Fig. 8), were distributed as follows: 44 percent of respondents agree with the statement and 32 percent fully agree. So, the total number of respondents who positively evaluate the statement makes up 76 percent. This shows that the three quarters of employers recognize the significance of cooperation with an educational institution as it is useful for the employee, the higher education institution and the employer in carrying out contracted researches and organizing qualification events whilst 6 percent of respondents answer that they are not sure if such cooperation is useful and 18 percent of respondents do not agree that such cooperation is beneficial.

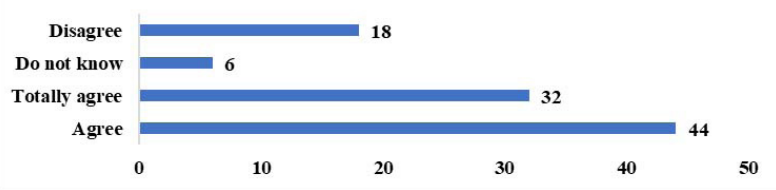

Figure 8. Relationship with an educational institution

Summarizing the respondents' answers it can be stated that the surveyed employers not only maintain contact with the higher education 
institutions but also perceive the meaning of such cooperation, because a positive mutual communication brings real benefits to all stakeholders.

Respondents' answers to the question “A working student brings innovations to the organization" (Fig. 9), were distributed as follows: 36 percent agree with the statement; 40 percent fully agree. In total, this makes up 76 percent of respondents' responses who have a positive attitude towards the fact that working students bring new information and innovations from a higher education institution to the organization. But 12 percent of respondents do not have any opinion or disagree with the statement.

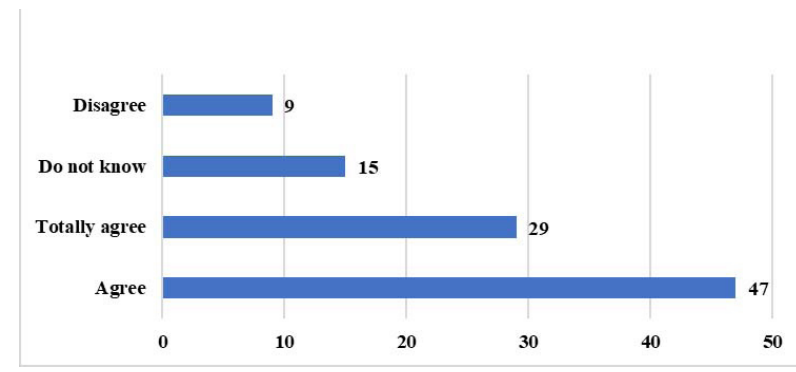

Figure 9. Studies and work activities

Summarizing the respondents' answers it can be stated that the interviewed employers perceive the importance of learning, the significance of innovations that an employee brings from a higher education institution to a specific organization. Thus, a mutually beneficial process takes place the student gains work experience in the workplace and a particular organization receives innovation from a higher education institution.

Respondents' answers to the question "Work during studies helps to develop general abilities: verbal communication; cooperation; leadership; teamwork; time planning; problem solving" (Fig. 10), were distributed as follows: the absolute majority of employers agree that general skills of studying employees develop especially favorably during their work practice - the answers "agree" or "strongly agree" make up from 70 percent to 100 percent. Only a very small proportion of respondents (ranging from 6 percent to 30 percent) say that they do not know or do not agree that the key competences are developed in the workplace. However, this is more related to possessing leadership competencies, so it is believed that these competencies are developed more in a managerial work and working students do not perform such work yet and the respondents tend to wait until they graduate.

It is obvious that employers positively assess not only professional but also general abilities of the studying employees and believe that these abilities are developed in a favorable direction in the workplace. 


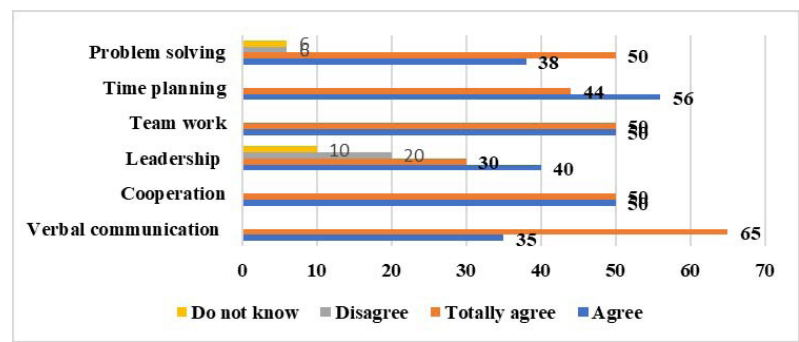

Figure 10. Development of general skills

Respondents' answers to the question "Remote learning can help to solve the problems of work and study compatibility" (Fig. 11), were distributed as follows: the total percentage of those who agree and completely agree with the statement make up 70 percent. 18 percent state that they have no opinion on the matter, 6 percent state that they disagree or strongly disagree with the statement.

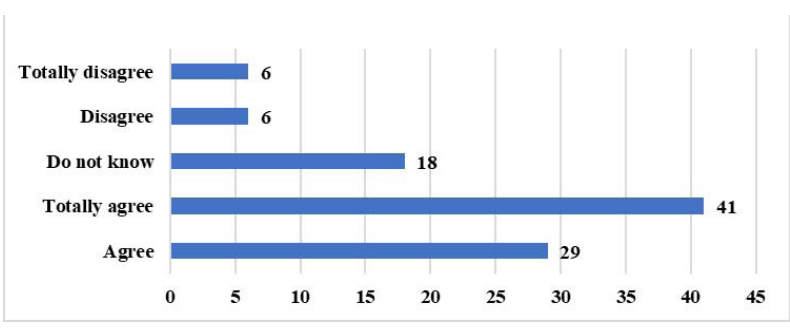

Figure 11. Remote learning opportunities

Summarizing the respondents' answers it can be stated that the surveyed employers positively evaluate the opportunities provided by remote learning for the studying employees.

When asked to submit proposals and recommendations for the effective work and study balance, the following answers were received: theoretical preparation is sufficient, but practice is lacking. Pre-submission of schedules and coordination with the work schedule. It is important to improve working students' ability to plan their time; personal characteristics of the studying staff (flexibility, cooperation, initiative). Kindness of teachers. The most important aspect for the respondents is students' motivation to work and study. 


\section{Conclusions}

- The organizations involved in the study state that they have studying employees. Employers perceive such employees as beneficial to their organization; encourage employees to study; enable them to work and study and wish that in the future such employees after graduation could work in their organization.

- Possibilities of combining studies and work: appropriate communication, cooperation of stakeholders, choice of optimal workload, choice of work activities related to studies. Possibilities of combining studies and work depend on the effectiveness of cooperation between the higher education institution, the employer and a person himself. Employers want timely to receive information about the student's session time, examinations, changes in the schedule. Effective communication with the higher education institution is considered to be an important aspect not only for the studying employee but also a useful factor implementing activities in the organization.

- Student performs mandatory activity functions both in the workplace and in the higher institution, so his or her personal qualities are important for timely and accurate performance of tasks in both organizations. Punctuality, time planning, ability and willingness to learn, information and communication technology (ICT) skills, psychological stability, flexibility, ability to seek for help, team work, cooperation, desire to acquire the subject competencies required at work are necessary requirements for the studying worker.

\section{References}

Beerkens, M., Mägi, E., \& Lill, L. (2011). University studies as a side job: Causes and consequences of massive student employment in Estonia. Higher Education, 61(6), 679-692. Retrieved from: https://link.springer.com/article/10.1007/s10734-010-9356-0

Deriname studijas ir moksla [Combining studies and science] (2020). Retrieved from: https://www.vdi.lt/PdfUploads/DerinameMokslaStudijas.pdf

Lietuvos studijų būkle [State of Lithuanian Studies] (2020). Retrieved from: https:// strata.gov.lt/images/tyrimai/2020-metai/svietimo-politika/20200901-Lietuvos-studijubukle.pdf

Lukšas, G. (2019). Studiju ir darbines veiklos derinimas [Combining work and studies]. Retrieved from: https://www.vdu.lt/cris/handle/20.500.12259/93413

Mane, F., Corbella, T. (2017). Developing and running an establishment skills survey - Guide to anticipating and matching skills and jobs. Retrieved from: https://www.etf.europa.eu/ en/publications-and-resources/publications/developing-and-running-establishmentskills-survey-guide

Neyt, B., Omey, E., Verhaest, D., \& Baert, S. (2017). Does Student Work Really Affect Educational Outcomes? A Review of the Literature. Maastricht: Global Labor 
Organization (GLO) Discussion Paper No. 121. Retrieved from: https://www.econstor. eu/bitstream/10419/169354/1/GLO-DP0121.pdf

Sanchez-Gelabert, A., Figueroa, M., \& Elias, M. (2017). Working whilst studying in higher education: The impact of the economic crisis on academic and labour market success. European Journal of Education, 52(2), 232-245. Retrieved from: https://onlinelibrary. wiley.com/doi/abs/10.1111/ejed.12212

Studiju ir darbinés veiklos derinimas [Combining work and studies] (2019). Retrieved from: https://hdl.handle.net/20.500.12259/93413 pa

Šerènaitè, A. (2020). Dirbti pagal specialybe - tik ipusejus studijas [Work according the speciality only in the middle of studies]. Retrieved from: http://manokarjera.cv.lt/ Default4.aspx?ArticleId = cb5d598f-d30b-476e-9fb6-d88520b73375

Urbonaitė - Vainienė, I., Brunalas, B. (2018). Tyrimas: kiek studentu dirba, kiek skursta, kaip jie jaučiasi, kur gyvena [Research: how many students work, how many fall into poverty, how they feel, where they live]. Retrieved from: https://www.respublika.lt/lt/naujienos/ lietuva/kitos_lietuvos_zinios/tyrimas_kiek_studentu_dirba_kiek_skursta_kaip_jie_jauciasi_ kur_gyvena. 